Pre-print of Montes, Juan Antonio et Sánchez Ferrer, Antoni «Levels of ATP in different organic wastes under composting conditions» in Journal of Chemical Technology and Biotechnology (Wiley), Vol. 83, Issue 9 (September 2008), p. 1226-1229. The final version is available at DOI 10.1002/jctb.1928

\title{
Levels of ATP in different organic wastes under composting conditions
}

\author{
Juan Antonio Montes and Antoni Sánchez* \\ Department of Chemical Engineering \\ Universitat Autònoma de Barcelona \\ Bellaterra (Cerdanyola, 08193-Barcelona, Spain) \\ *Corresponding author: Dr. Antoni Sánchez (Phone: 34-935811019; Fax: 34-935812013; Email: \\ antoni.sanchez@uab.cat)
}

Short title: ATP in composting of solid wastes.

\begin{abstract}
BACKGROUND: The concentration of ATP in selected samples from the composting process of several organic wastes (municipal solid wastes, wastewater sludge, animal by-products and cow manure) has been determined in order to characterize the aerobic biological activity of such wastes.

RESULTS: The values obtained ranged from 0 (in old stable compost from cow manure) to $0.07 \mu \mathrm{mol}$ ATP/g dry matter in thermophilic samples of municipal solid wastes composting. In general, it was found that ATP levels were in agreement with the stage of the composting process (initial stage, thermophilic period and maturation). On the other hand, ATP concentration correlated well $(\mathrm{p}<0.05)$ with the overall respiration activity during a whole composting process of municipal solid waste at full scale.
\end{abstract}

CONCLUSION: ATP concentration can be used to determine the biological activity of organic solid wastes in different stages of their biological treatment and to predict compost stability prior to soil application.

Key words: Animal by-products, ATP, Composting, Manure, Municipal solid waste, Wastewater sludge. 


\section{INTRODUCTION}

Composting can be defined as a biological process in which organic solid matter is biodegraded under aerobic conditions. In recent years, interest in composting has grown because of the necessity to find sustainable and environmentally friendly technologies for solid waste management.

One of the crucial aspects in the study of composting is the development of reliable techniques to measure and monitor the aerobic biological activity of the process. An important group of methods is based on specific biochemical properties such as RNA content, ${ }^{1}$ several enzymatic activities such as dehydrogenase activity ${ }^{2-4}$ or products related to metabolism of aerobic microorganisms. As ATP is produced as an energy source during the process of cellular respiration, its role as a parameter to quantify the biological activity of compost or sludge samples has been highlighted in recent works. ${ }^{5-7}$ ATP concentration has been also proposed as a parameter to estimate viable biomass of a compost intended for soil application. ${ }^{6-7}$

The aim of the present study is the determination of ATP concentration in a wide variety of composting samples not previously studied, which represent different biodegradable materials and stages in the composting process. Also, the levels of ATP found for municipal solid wastes are compared and correlated with the respiration index throughout a whole composting process.

\section{MATERIALS AND METHODS}

\section{Composted wastes}

The organic wastes were obtained from the composting plant of Jorba (Barcelona, Spain). Organic fraction of municipal solid wastes, raw wastewater sludge, animal by-products (from slaughterhouses) and cow manure were used. The general properties of these wastes can be found elsewhere. ${ }^{8,9}$

\section{Composting system and sampling}

The composting plant of Jorba uses the typical windrow system. The detailed description of the composting plant operation and sampling has been explained in previous studies. ${ }^{10}$

\section{ATP determination}

ATP concentration was determined according to manufacturer's instructions after extracting ATP from the representative sample of the solid organic waste (3 replicates). The results are expressed as 
an average value with standard deviation. The typical deviation found in triplicate samples was in the range of 5-10\%. A commercial kit from Sigma-Aldrich (Barcelona, Spain) was used (Adenosine 5'triphosphate Bioluminescent Assay Kit, FL1KT). Extraction of ATP from the solid sample was carried out according to the method proposed by Archibald et al. ${ }^{11}$ A luminometer was used for the readings of luminescence (Luminescence Spectrometer LS55, Perkin Elmer Instruments).

Static respiration index (SRI)

SRI was determined using a static respirometer, which has been explained in a previous work. ${ }^{8}$ Values of SRI are expressed as mg of oxygen consumed.g organic matter ${ }^{-1} \cdot \mathrm{h}^{-1}$.

\section{Routine analytical methods}

Moisture and organic matter were determined according to the standard procedures. ${ }^{12}$

\section{RESULTS AND DISCUSSION}

\section{Levels of ATP in different organic wastes}

The summary of ATP concentrations found in different organic wastes at different stages of the composting process is shown in Table 1 . The highest levels of ATP concentration $(>0.05 \mu \mathrm{mol} / \mathrm{g}$ dry matter) were found for municipal solid wastes and animal by-products, and in both cases, in the thermophilic stage of the composting process (temperatures higher than $65^{\circ} \mathrm{C}$ were recorded in this period, data not shown). On the other hand, wastewater sludge samples presented lower levels of ATP concentration, even when thermophilic temperatures were reached (higher than $65^{\circ} \mathrm{C}$ after three weeks of composting). This is in accordance with other studies that have shown a high biological activity for municipal solid waste using RNA concentration ${ }^{2}$ and a lower level of respiratory activity for wastewater sludge compared to municipal solid waste, especially for anaerobically digested sludge. ${ }^{9}$ Although there are no references on the biological activity of animal by-products composting, it seems evident from the results obtained that this material presents a high activity, which makes composting a suitable technology for its treatment. In the case of cow manure, material in the maturation stage (8 weeks) still showed a moderate ATP concentration $(0.0304 \mu \mathrm{mol} / \mathrm{g}$ dry matter), whereas in a very stable compost (25 weeks of composting), no ATP was detected. Unfortunately, samples from the early stage of composting process could not be analysed for comparison with other organic materials. 
Some literature results of ATP concentration in composting processes were reviewed for comparison with the present study. They are also presented in Table 1. Most of ATP concentrations were quite similar to those of the present work. For instance, the level of ATP in sewage sludge ${ }^{13}$ was lower than the levels of pulp and paper products ${ }^{14}$ or straw and pig slurry, ${ }^{15}$ which are presumably more biologically active materials. The knowledge of the biological activity of organic wastes is an aspect of special relevance for designing and managing composting processes, since biological activity is strongly related to the operation of composting plants, in crucial points such as air or bulking agent requirements. ${ }^{9}$ However, some of the results found were very low $^{7}$ or very high ${ }^{6}$ in comparison with those of the present work, which is probably due to differences in the ATP extraction procedure. In relation to this, it should be noted that a universal method for ATP extraction does not exist, and there are several reagents used for extraction such as phosphoric acid, ${ }^{7}$ Tris-EDTA buffer, ${ }^{6}$ whereas in other works it is not explained in detail. ${ }^{5,15}$ In the present work, several extracting reagents proposed by previous works were tested, ${ }^{6,7}$ and the best results in terms of recovery of ATP activity were obtained with the protocol proposed by Archibald et al., ${ }^{11}$ in which $2.5 \%$ trichloroacetic acid (TCA), and 20mM $\mathrm{Na}_{4}$-EDTA are used. Finally, it is worthwhile to mention that although no results have been found in literature for municipal solid waste and animal by-products, it can be again concluded from Table 1 that these wastes are among the highly biologically active materials.

\section{Comparison with respiration activity}

A complete evolution of a municipal solid waste composting process is presented in Figure 1. In this process, respiration index and ATP concentration showed a similar profile, which was related to an initial rapid development of aerobic microbial communities that reached a maximum value in the thermophilic period (approximately from second to sixth week) followed by a maturation stage in which the level of biological activity clearly decreased. This type of profiles of ATP concentration has been previously observed with other wastes ${ }^{6,7}$ and using other techniques to determine the overall biological activity, such as dehydrogenase activity. ${ }^{4}$ In fact, the results of ATP concentration and respiration activity obtained from this study correlated well $(\mathrm{p}<0.05)$ with a slope of 42.5 to convert from ATP concentration to respiration index. However, it can be easily observed from Figure 1 that during the first weeks of composting (first 40 days) the ATP concentration evolution was delayed with 
respect to respiration index (this delay was graphically estimated and the value was in the range of 510 days), whereas in the maturation stage this delay practically disappeared. Although the exact reason for this behaviour is unknown, and no literature has been found to compare ATP and respiration index using municipal solid wastes, it can be hypothesised that ATP is available for analytical determination after a period of composting and only when organic matter has been degraded to some extent (Figure 1). On the other hand, respiration activity, since it is a global biological parameter, can be detected from the beginning of the composting process. Other results with pig manure have shown that ATP and respiration index correlated relatively well during time,${ }^{6}$ although the number of experimental points in that study was much lower than those of the present work. In any case, both ATP concentration and respiration index showed that the compost obtained was well stabilised according to international regulations, ${ }^{12}$ which confirmed the feasibility of these tests to characterize organic materials intended for soil application.

In conclusion, this work has demonstrated that ATP concentration can be a useful and a relatively simple tool to determine the level of biological activity in different stages of the composting process. The differences in ATP concentration found for the organic wastes analysed can be also of interest to predict their behaviour in the process.

\section{ACKNOWLEDGEMENT}

Financial support was provided by the Spanish Ministerio de Educación y Ciencia (Project CTM200600315/TECNO).

\section{REFERENCES}

1 Liwarska-Bizukojc, E., Ledakowicz, S., 2001. RNA assay as a method of viable biomass determination in the organic fraction of municipal solid waste suspension. Biotechnol. Lett. $23,1057-1060$

2 Wong, J.W.C., Fang, M., 2000. Effects of lime addition on sewage sludge composting process. Wat. Res. 34, 3691-3698. 
3 Tiquia, S.M., Wan, J.H.C., Tam, N.F.Y., 2002. Dynamics of yard trimmings composting as determined by dehydrogenase activity, ATP content, Arginine ammonification, and nitrification potential. Process Biochem. 37, 1057-1065.

4 Barrena, R., Vázquez, F., Sánchez, A., 2008. Dehydrogenase activity as a method for monitoring the composting process. Bioresource Technol. 99, 905-908.

5 Horiuchi, J.I., Ebie, K., Tada, K., Kobayashi, M., Kanno, T., 2003. Simplified method for estimation of microbial activity in compost by ATP analysis. Bioresource Technol. 86, 95-98.

6 Tiquia, S.M., 2005. Microbiological parameters as indicators of compost maturity. J. Appl. Microbiol. 99, 816-828.

7 Ros, M., García, C., Hernández, T., 2006. A full-scale study of treatment of pig slurry by composting: Kinetic changes in chemical and microbial properties. Waste Manage. 26, 11081118.

8 Barrena, R., Vázquez, F., Gordillo, M.A., Gea, M.T., Sánchez, A., 2005. Respirometric Assays at Fixed and Process Temperatures to Monitor Composting Process. Bioresource Technol. 96, 1153-1159.

9 Gea, M.T., Barrena, R., Artola, A., Sánchez, A., 2004. Monitoring the Biological Activity of the Composting Process: Oxygen Uptake Rate (OUR), Respirometric Index (RI) and Respiratory Quotient (RQ). Biotechnol. Bioeng. 88, 520-527.

10 Barrena, R., Pagans, E., Faltys, G., Sánchez, A., 2006. Effect of inoculation dosing on the composting of source-selected organic fraction of municipal solid wastes. J. Chem. Technol. Biotechnol. 81, 420-425.

11 Archibald, F., Méthot, M., Young, F., Paice, M.G., 2001. A simple system to rapidly monitor activated sludge health and performance. Wat. Res. 35, 2543-2553.

12 U.S. Department of Agriculture and U.S. Composting Council, 2001. Test methods for the examination of composting and compost, Edaphos International, Houston.

13 Tseng, D.Y., Chalmers, J.J., Touvinen, O.H., 1996. ATP measurement in compost. Compost Sci. Util. 4, 6-17. 
14 Vikman, M., Karjomaa, S., Kapanen, A., Wallenius, K., Itavaara, M. 2002. The influence of lignin content and temperature on the biodegradation of lignocellulose in composting conditions. App. Microbiol. Biotechnol. 59, 591-598.

15 Eiland, F., Klamer, M., Lind, A.M., Leth, M., Baath, E., 2001. Influence of initial C/N ratio on chemical and microbial composition during long term composting of straw. Microb. Ecol. 41, 272-280. 


\section{TABLES}

Table 1: Levels of ATP obtained for the different wastes analysed. Comparison with some levels of ATP previously reported in literature.

\begin{tabular}{|c|c|c|c|}
\hline Waste & $\begin{array}{l}\text { Composting time } \\
\text { and conditions }\end{array}$ & $\begin{array}{l}\text { ATP concentration } \\
(\mu \mathrm{mol} / \mathrm{g} \text { dry matter })^{*}\end{array}$ & Reference \\
\hline Municipal solid waste & Full-scale during 1 week & $0.0045 \pm 0.0007^{\mathrm{a}}$ & This work \\
\hline Municipal solid waste & Full-scale during 3 weeks & $0.062 \pm 0.005^{\mathrm{b}}$ & This work \\
\hline Wastewater sludge & Full-scale during 1 week & $0.008 \pm 0.002^{c}$ & This work \\
\hline Wastewater sludge & Full-scale during 3 weeks & $0.011 \pm 0.002^{\mathrm{d}}$ & This work \\
\hline Animal by-products & Full-scale during 1 weeks & $0.019 \pm 0.001^{\mathrm{e}}$ & This work \\
\hline Animal by-products & Full-scale during 3 weeks & $0.054 \pm 0.008^{f}$ & This work \\
\hline Cow manure & Full-scale during 8 weeks & $0.030 \pm 0.001^{\mathrm{g}}$ & This work \\
\hline Cow manure compost & Full-scale during 25 weeks & $0.000 \pm 0.001^{\mathrm{h}}$ & This work \\
\hline Wheat bran & Laboratory scale during 8 days & $0.004-0.02$ & 5 \\
\hline Pig manure & Full-scale during 10-18 weeks & $0.1-0.5$ & 6 \\
\hline Pig manure & Full-scale during 13 weeks & $0.0002-0.0006$ & 7 \\
\hline Sewage sludge & Laboratory scale incubations & $0.0002-0.02$ & 13 \\
\hline Pulp and paper products & Laboratory scale during 7 weeks & $0.02-0.07$ & 14 \\
\hline Straw and pig slurry & Pilot scale during 12 months & $0.01-0.03$ & 15 \\
\hline
\end{tabular}

* ATP values obtained in this work are presented as an average with standard deviation, with different letters indicating significant statistical difference $(\mathrm{p} \leq 0.05)$. For references $5,6,7,13,14$ and 15 , the whole range of ATP values obtained is presented. 


\section{CAPTIONS TO FIGURES}

Figure 1: Evolution of ATP concentration, static respiration index and organic matter content for municipal solid waste composting.

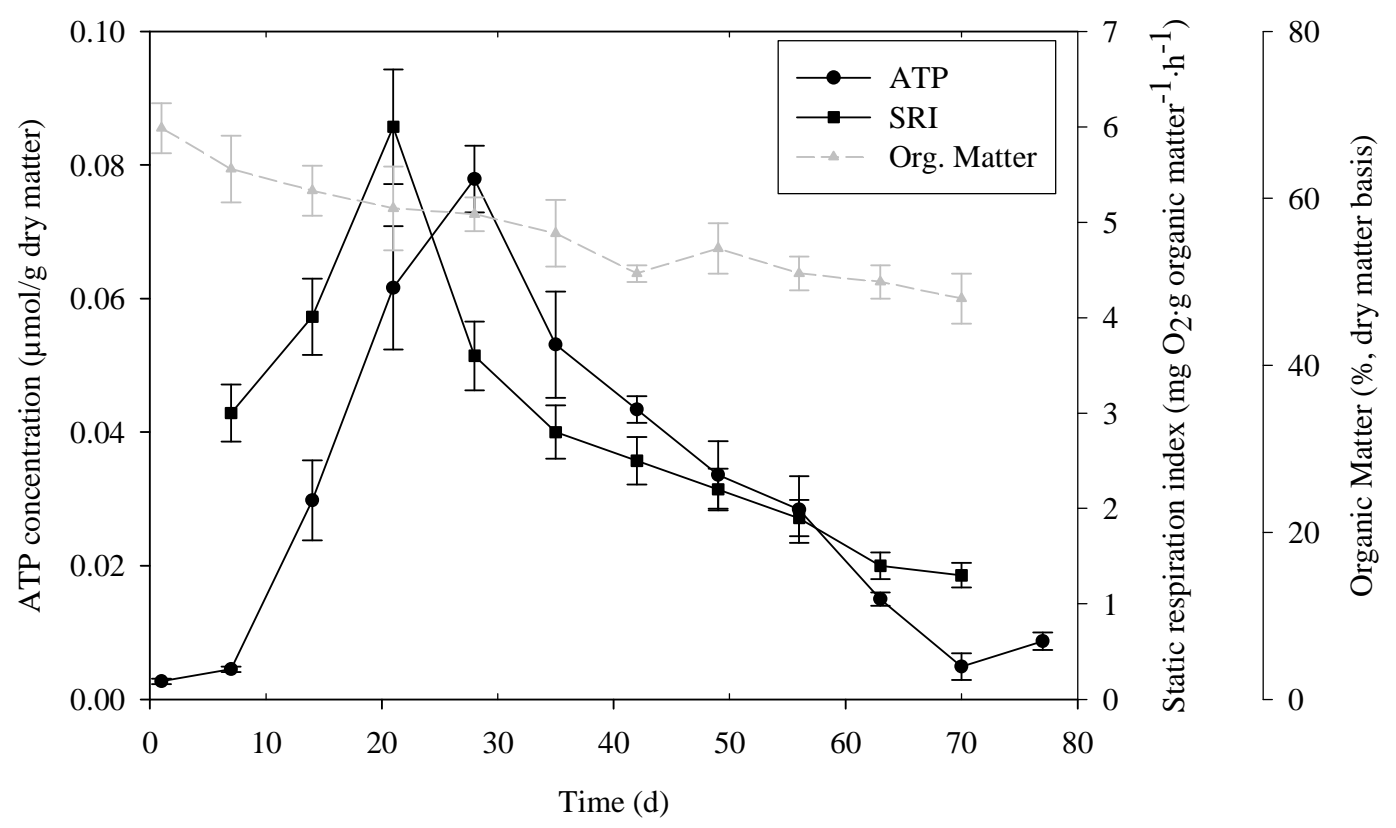

